Race And Rights 

Early American Places is a collaborative project of the University of Georgia Press, New York University Press, Northern Illinois University Press, and the University of Nebraska Press. The series is supported by the Andrew W. Mellon Foundation. For more information, please visit www.earlyamericanplaces.org.

ADVISORY BOARD

Vincent Brown, Duke University

Stephanie M. H. Camp, University of Washington

Andrew Cayton, Miami University

Cornelia Hughes Dayton, University of Connecticut

Nicole Eustace, New York University

Amy S. Greenberg, Pennsylvania State University

Ramón A. Gutiérrez, University of Chicago

Peter Charles Hoffer, University of Georgia

Karen Ordahl Kupperman, New York University

Joshua Piker, University of Oklahoma

Mark M. Smith, University of South Carolina

Rosemarie Zagarri, George Mason University 



\section{RACE AND Rights}

Fighting Slavery and Prejudice

in the Old Northwest, $1830-1870$

DANA ELIZABETH WEINER

NIU Press

DEKALB 
(C) 2013, 2015 by Northern Illinois University Press

Published by the Northern Illinois University Press

DeKalb, Illinois 60115

First printing in paperback, 2015

All rights reserved

Portions of chapters 3 and 4 previously appeared as "Anti-Abolition Violence and Freedom of Speech in Peoria, Illinois, 1835-1848," Journal of Illinois

History, 11 (2008): 179-204.

Library of Congress Cataloging-in-Publication-Data

Weiner, Dana Elizabeth.

Race and rights : fighting slavery and prejudice in the Old Northwest, 18301870 / Dana Elizabeth Weiner.

p. $\mathrm{cm}$.

Includes bibliographical references and index.

ISBN 978-0-87580-457-6 (cloth : alk. paper)

ISBN 978-0-87580-713-3 (pbk.)

ISBN 978-1-60909-072-2 (electronic)

1. Antislavery movements-Northwest, Old-History-19th century.

2. African Americans-Legal status, laws, etc.-Northwest, Old-History19th century. 3. African Americans-Northwest, Old-Social conditions19th century. 4. Race discrimination-Law and legislation-Northwest, Old-History-19th century. 5. Northwest, Old-Race relations--History19th century. 6. Northwest, Old-History-1775-1865. I. Title.

F484.3.W45 2013

305.80097709'034-dc23

2012037642

The Jacket image is from the painting, The Underground Railroad (1893 Oil on Canvas, 52 3/16 x $761 / 8$ in) by Charles T. Webber. 
For my parents 
